\title{
Maturity Business Process Management at Companhia Energética de Minas Gerais
}

Mayra Evangelista Neves ${ }^{1}$, FUMEC University, Belo Horizonte, Minas Gerais, Brazil Fernando Silva Parreiras ${ }^{2}$, FUMEC University, Belo Horizonte, Minas Gerais, Brazil Eric de Paula Ferreira ${ }^{3}$, FUMEC University, Belo Horizonte, Minas Gerais, Brazil Fábio Corrêa ${ }^{4}$, FUMEC University, Belo Horizonte, Minas Gerais, Brazil

\section{RESUMO}

Objetivo: Avaliar a maturidade da Companhia Energética de Minas Gerais em gestão de processos de negócio.

Referencial teórico: A Maturidade em Processos é o grau de explícita definição, gestão, mensuração, controle e efetividade que um processo possui. Essa Maturidade prima por avaliar a situação atual de modo a direcionar ações de melhoria.

Desenho/metodologia/abordagem: Coleta de dados, por meio de questionário, obtendo a amostra de 729 respondentes, e análise por meio de modelagem de equações estruturais.

Resultados: A empresa analisada encontra-se no nível 4, sendo a promoção de ações de reconhecimento dos responsáveis pelos processos e alinhamento dos sistemas de informações às necessidades dos clientes algumas ações para elevação deste estágio.

Implicações de pesquisa, práticas e sociais: A maturidade identificada permite a empresa promover ações de melhoria em seus processos, acarretando em impactos sociais oriundos da prestação de serviços à comunidade.

Originalidade/valor: Pela perspectiva teórica, permite a comparação dos resultados com outras entre empresas; porquanto, empiricamente, contribui com a referida empresa com ações para elevação do estágio identificado.

Palavras-chave: BPM. Gestão de Processos de Negócio. BPMMM; Modelo de Maturidade. Setor Elétrico.

\section{ABSTRACT}

Purpose: This study aims to assess the maturity of Companhia Energética de Minas Gerais in business process management. Theoretical framework: Business Process Management is an alternative to the standard departmentalized structure. This alternative presents Maturity in Processes as the degree of explicit definition, management, measurement, control and effectiveness that a process has. Thus, this Maturity excels in assessing the current situation in order to direct improvement initiatives and control the development of what is being measured.

Design/methodology/approach: Data was collected through a questionnaire, obtaining a sample of 729 respondents, and the data was analyzed using the structural equation modeling technique.

Findings: The company being studied is at level 4, and is called quantitatively managed, where the promotion of actions to recognize those responsible for the processes and alignment of information systems to customer needs are some of the actions needed to increase this stage.

Research, Practical \& Social implications: Through the maturity identified, Companhia Energética de Minas Gerais can promote actions to improve its processes, resulting in social impacts arising from the provision of services to the community.

Originality/value: From a theoretical perspective, this study contributes by making use of a maturity model and by showing its results for comparisons between companies; because, empirically, it contributes to that company so that it is aware of its current stage and actions to increase that stage.

Keywords: BPM; business process management; BPMMM; maturity model; electrical sector.

1.mayra@cemig.com.br,

http://orcid.org/0000-0001-6609-6349;

2.fernando.parreiras@fumec.br, http://orcid.org/0000-0002-9832-1501; 3. eric.p.f@gmail.com, http://orcid.org/0000-0002-7513-501X; 4. Rua Cobre, 200 - Cruzeiro, Belo Horizonte - MG. CEP: 30310-190, fabiocontact@gmail.com, http://orcid.org/00000002-2346-0187.

NEVES, M.E.; PARREIRAS. F.S.; FERREIRA, E.P.; CORRÊA, F. Maturity Business Process Management at Companhia Energética de Minas Gerais. GEPROS. Gestão da Produção, Operações e Sistemas, v.16, nº 4, p. 115 $136,2021$. 


\section{INTRODUCTION}

The scarcity of resources and the demand for a higher level of quality in the products and services delivered by organizations culminate in the need to implement robust management practices aimed at achieving progressively better results. In this context, the management of business processes (Business Process Management - BPM) is applied in the value chain of organizations, both in routine and to generate improvements in the operation, in a way that is widespread throughout the world (HAMMER, 2007; HARMON, 2018; MEIDAN et al., 2017; ROSEMANN, 2014; LIZANO-MORA; PALOS-SÁNCHEZ; AGUAYO-CAMACHO, 2021).

In the process view there is greater convergence of objectives of the executors and higher service levels, since the team involved is focused on the final result. According to Cobb (2003) and Harrington (2006), BPM is able to contribute to business excellence by ensuring a model work uniform, but for process management to be effective, it must transcend management by departments, because the customer sees the final delivery and not the area responsible for the failure.

In this context, maturity models emerged to assess the organization's capabilities in a given area of knowledge or management. Capabilities, in the context of a BPM maturity model, can be understood as a set of skills, tools or knowledge necessary for an organization to be able to achieve the process result goals (VAN LOOY; DE BACKER; POELS, 2011; VAN LOOY, 2014; SZELAGOWSKI; BERNIAK-WOŹNY, 2020). Many business process management maturity models (BPMMM) have been developed (MCCORMACK; JOHNSON, 2001; FISHER, 2004; ROSEMANN; BRUIN, 2005; HAMMER, 2007; OMG, 2008; FROGER et al., 2019 ; NEVES; FERREIRA; PARREIRAS, 2020) and the application, as well as the empirical evaluation of these models, are crucial to find the ideal method for different types of organizations and segments.

Based on these reflections, this study aims to assess the maturity of business process management at Companhia Energética de Minas Gerais (Cemig), applying relevant models from the literature. This investigation is justified by its theoretical-empirical character, given that it is circumscribed within the scope of a Research and Development (R\&D) Program. Thus, after this introduction, the structure of the text follows: (2) theoretical framework on the 
themes that support the study; (3) theoretical framework of this research; (4) methodological procedures; (5) results; and (6) final considerations.

\section{THEORETICAL FOUNDATION}

\subsection{Business process management}

Organizations adopt the departmentalized model as a standard structure, acting by specific areas of knowledge. This model proved to be ineffective, since the focus of each agent is directed towards their surroundings, motivating the choice of suboptimal decisions for the company and its customers (HAMMER; HERSHMAN, 2017). As an alternative to this traditional model, the business process management approach, BPM, was developed.

According to Van Looy, De Backer and Poels (2011), a business process can be defined as a coherent repetitive set of activities, having as its starting point a business event, performed by people and machines, within an organization or between several, aiming to achieve corporate goals and always aimed at customers, whether internal or external. It is worth noting that the business process, therefore, does not refer to any process in the organization, but only to those that contribute to achieving goals, which exist to meet the needs of customers, adding value to the company's deliverables. Hammer (2007) corroborates this definition, stating that a business process is a set of activities that demand one or more inputs that create an output that represents value for the customer who receives it.

BPM makes it possible to capture synergies between areas, work smoothly in the company, firmly target the customer, eliminate tasks that do not add value, among other benefits. However, the effective implementation of this management model demands great effort from the technical, managerial and directive staff. In addition to the commitment of agents being essential, the operationalization of BPM requires dedication and is carried out in stages. The design and improvement of a business process involves numerous elements, such as raising the current sequence of steps necessary to carry it out, designating those responsible for each step, how to do them, the level of criticality of activities, as well as identifying opportunities for improvement and capturing them, through an action plan.

According to CBOK (2013), the process management lifecycle, represented in Figure 1, is composed of stages, namely: 1) planning, setting goals to be achieved, outlining the business value chain, identifying the needs to be met, as well as environmental restrictions and control variables for conducting the studies; 2) qualitative and quantitative analysis of the 
risks inherent to the process; 3) drawing, outlining the ideal process to be pursued as a reference in the next steps; 4) implementation, executing the planned improvements to achieve the ideal process, ensuring the quality and meeting deadlines of the actions raised; 5) monitoring and control, measuring the results of the process after taking the actions; and 6) refinement, adapting initiatives, if the result does not meet the previously established goal, and standardizing good practices, if the goal has been reached.

Figure 1 - Process management lifecycle

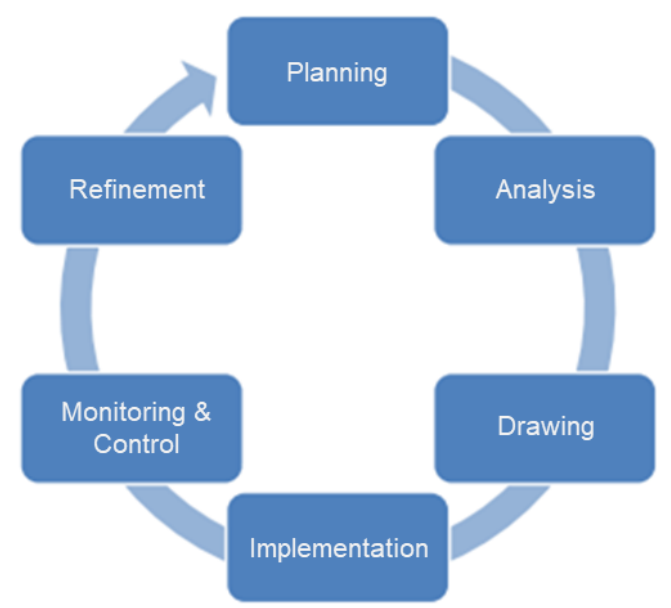

Source: CBOK (2013, p. 52).

Thus, the full immediate implementation of BPM was not feasible, models were developed with the objective of evaluating the maturity of management by business processes in companies.

\subsection{Business process management maturity models}

Maturity models originated in the software segment with Nolan, in 1973, (NOLAN, 1973) and with Philip Crosby, in 1980, (CROSBY, 1980) were applied in a directed way in management and adopted in diversified themes, such as Quality Management (MARQUES et al., 2020) and Knowledge Management (ESCRIVÃO; SILVA, 2021). Crosby (1980) proposes the notion of maturity by developing a five-level scale that organizations would go through when adopting quality practices. 
Maturity can be defined as the guarantee that business processes are capable of performing good results over time, developing competencies both for the individual process and for the entire organization (HAMMER, 2007). Humphrey (1988) also defines process maturity as the degree of explicit definition, management, measurement, control and effectiveness that a process has.

According to Iversen, Nielsen and Norbjerg (1999), maturity models aim to assess the current situation in order to guide improvement initiatives and control the evolution of what is being measured. The development of maturity models has become a widespread topic in the literature in recent decades and Kalinowski (2016) identified more than 150 different models available that have already been published. A large part of these studies were dedicated to developing the models and few are directed to testing and improving what was developed. According to Rosemann and Bruin (2005), the common basis for most of these models was the Capability Maturity Model (CMM) developed by the Software Engineering Institute at Carnegie Mellon University.

Various audiences may be interested in applying BPM maturity models in a company, such as senior management, consultants and process managers; but all of these have common goals. They seek confidence that the necessary changes, indicated by the model, will bring better results and that there is no other initiative that would bring more value to the company, and this should be clear to the evaluators (HELGESSON; HÖST; WEYNS, 2012).

\section{THEORETICAL FRAMEWORK}

The management of business processes assumes representation in the business sphere, in contrast to the departmentalized model (HAMMER; HERSHMAN, 2017). Nevertheless, it is relevant to assess the degree of maturity of this management, as this supports the development of individual and organizational skills (HAMMER, 2007). However, Kalinowski (2016) identified more than 150 different models to measure maturity and, therefore, it became necessary to identify which would be consistent with the intent of this research.

In this sense, Neves, Ferreira and Parreiras (2020) studied 14 maturity models in order to identify BPM-oriented structures. These models were analyzed by this research, considering the requirements of scope, temporality, purpose and the existence of a data collection instrument. Thus, it was assumed that the selection of one or more structures, based on these criteria, would be a plausible means of identifying one applicable to this research. 
Based on these requirements, the Business Process Orientation (BPO) and Process and Enterprise Maturity Model (PEMM) models, respectively promulgated by McCormak (2001) and Hammer (2007), were identified as relevant. Figure 2 highlights this selection process, supported by the aforementioned criteria, as well as points out six structures specific to the software context (dotted boxes).

Figure 2 - Selection criteria for BPM maturity models

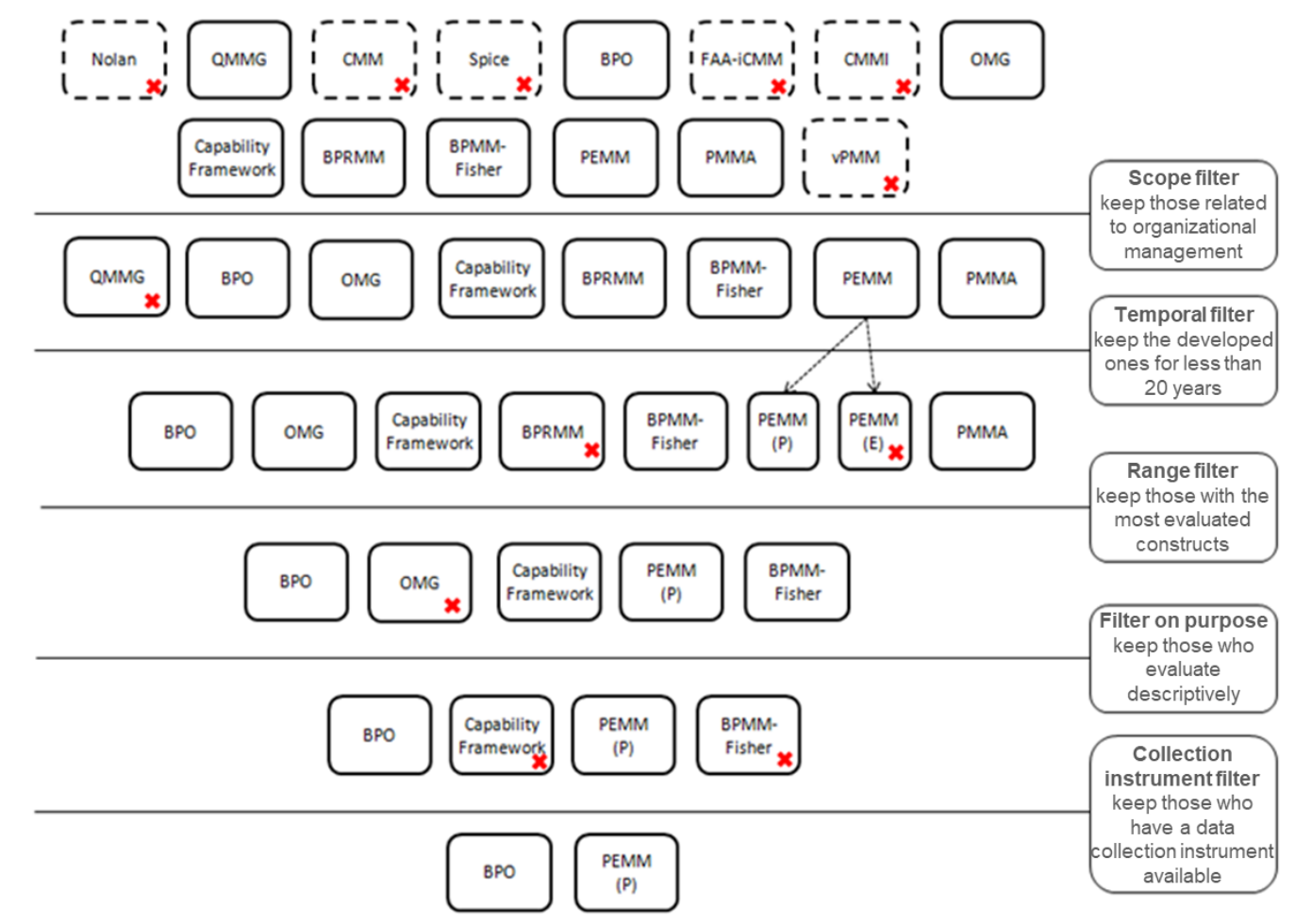

Source: Research data (2021).

In view of the BPO and PEMM models, studies by Cardozo (2015) and Cardozo and Rocha (2017) were found, which indicate a data collection instrument oriented towards these structures, which was adopted in this research. These studies advocate the existence of five constructs, consisting of indicators, which tend to influence the degree of maturity in process management in a given context.

The construct "Process design" contemplates the specification of how the process will be executed, considering: i) purpose, being the conception and sequence of activities included in the organization's business process); ii) context, related to the interaction between business 
processes and other internal processes); iii) documentation that gives form and support to the processes; iv) use and update of process documentation; v) segmentation of business processes adhering to customers and market (CARDOZO, 2015; CARDOZO; ROCHA, 2017).

The construct "Process executors" considers aspects inherent to the people who execute the processes, namely: i) knowledge about the processes and discernment of their impact on customers and on final performance; ii) problem solving, process improvement and decision making skills; and iii) worker behavior regarding the process (CARDOZO, 2015; CARDOZO; ROCHA, 2017).

The construct "Process Owner" determines the degree of process implementation in the organization and considers: i) the identity of the process owner in the organization; ii) activity, as content of the result of the work carried out in the process; and iii) authority of the owner as a decision maker in the process (CARDOZO, 2015; CARDOZO; ROCHA, 2017).

The construct "Process Infrastructure" contemplates the Information and Management Systems that support the process, considering: i) Information Systems to support interaction and communication between departments; and ii) Human Resources System that considers professionals aligned with the needs of the processes (CARDOZO, 2015; CARDOZO; ROCHA, 2017).

The construct "Process performance indicators" refers to the way the process is measured, dealing with: i) definition of process performance indicators; and ii) use of process performance indicators in everyday life (CARDOZO, 2015; CARDOZO; ROCHA, 2017)

These five constructs are made up of 15 indicators that, together, aim to understand the quality of process management and analyze the degree of maturity of this management within the organizational scope. Considering that they constitute the theoretical foundations of the construction of the research instrument presented by Cardozo (2015) and Cardozo and Rocha (2017), the referred instrument, as well as its constructs and indicators, are basic elements of the methodology used in this research.

\section{METHODOLOGICAL PROCEDURES}

This research is typified by its descriptive nature and quantitative approach, using the technique of statistical data analysis. The descriptive nature aims to elucidate aspects of the 
phenomenon investigated and emphasizes the accuracy of this description, which is materialized, in this research, by the articulation of characteristics of the investigated population and relationships established between the variables. Due to this nature, the quantitative approach is used, useful to analyze representative amounts of data from a numerical perspective. Thus, the data analysis technique makes use of statistical resources to understand the phenomenon. In summary, the aim is to understand the phenomenon investigated, that is, Cemig's maturity in business process management, by statistical means, in order to describe the findings with a view to enabling possible inferences or conclusions, which can be generalized.

Aiming to achieve the objective sought by this research, this investigation was carried out in three stages, namely: 1) to define the maturity assessment models that would be applied at Cemig; 2) empirically apply the data collection instrument from the models defined above; 3) analyze the collected data to assess the organization's BPM maturity level, as well as the strengths and interrelationships of the constructs.

For stage 1, it assumes those established in section 3 of this research, considering the BPO and PEMM models, treated in the studies by Cardozo (2015) and Cardozo and Rocha (2017), who indicate a data collection instrument oriented to these structures, this being adopted in this research. Consequently (step 2), the aforementioned instrument was made available in electronic format, according to the technological standards of the aforementioned company, and disclosed to employees of that organization. It is noteworthy that the organization agreed to this achievement, given that this research is circumscribed within the scope of a Research and Development Program (R\&D 594) of the same and, therefore, has a theoretical-empirical character.

Questions that deal with education and time in the company were assigned to this instrument, in order to understand the sample profile. Thus, the instrument is made up of 26 assertions (items), two of which are demographic and 24 refer to five first-order constructs, namely: "Process design", "Process executors", "Process owner", " Process infrastructure" and "Process performance indicators"; as well as by a second-order construct, called "Degree of maturity in organizational processes". Assertions were placed on a 7-point Likert scale, ranging from 1 "strongly disagree" to 7 "strongly agree".

The total population refers to the number of employees registered on the basis of the company's official corporate media. There are 5,351 Cemig's own employees and 3,394 
employees hired from outsourced companies, but who have a work post-type contract, that is, they are permanent at the company and actively participate in the processes of their areas. From this population of 8,745 employees, it is considered that the sample will consist of the number of respondents to the survey instrument, with a minimum estimated of five to 10 times the number of items in the survey instrument (SARSTEDT; RINGLE; HAIR, 2011), or that is, considering the 24 assertions pertaining to the constructs, a minimum of 240 respondents is necessary for the statistical purposes established here.

In sequence (step 3), the collected data were analyzed to assess the organization's BPM maturity level. Malhotra (2006, p. 154) defines quantitative research as one that "seeks to quantify data and, normally, applies some form of statistical analysis". Thus, to assess Cemig's maturity in business process management, the Structural Equation Modeling (SEM) technique was used as a multivariate analysis tool (HAIR et al., 2009). Each construct of the model (Figure 5) has 4 to 8 indicators that will measure it, which is elaborated and validated by Cardozo (2015) and replicated in this research. Arrows indicate the path or causal relationship between the elements and the unidirectional effect of one on the other.

Figure 3 - Theoretical model for measuring the degree of maturity in organizational processes

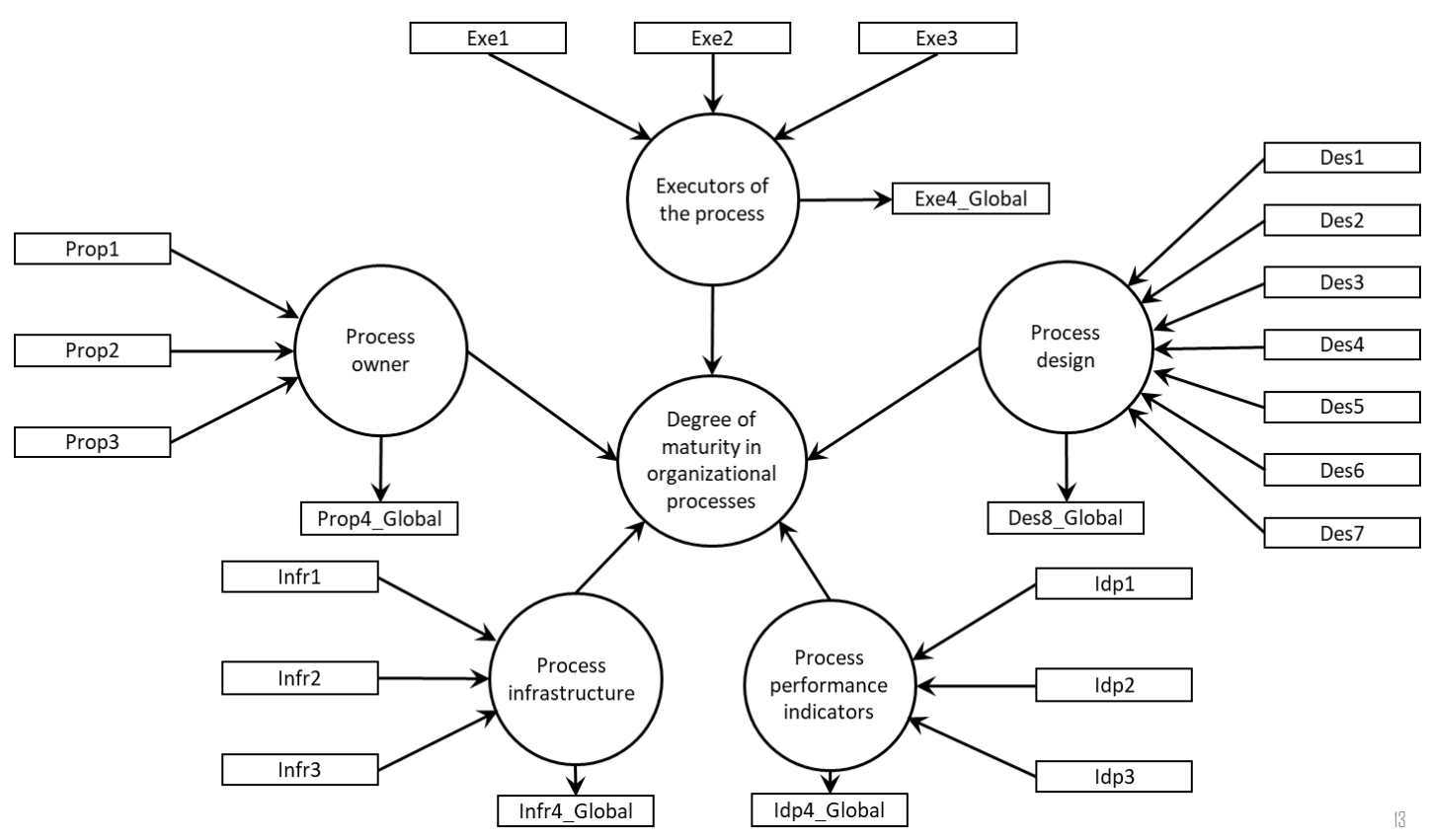

Source: Adapted from Cardozo (2015, p. 82). 
Through the responses obtained against the exposed model, the existence of outliers was analyzed, which are observations that present a response pattern different from the others (HAIR et al., 2009). Univariate outliers were diagnosed by standardizing the results, so that the mean of the variable was 0 and standard deviation 1 . Thus, univariate outliers were those observations with standardized scores outside the range of |4.00| (HAIR et al., 2009). Multivariate outliers, on the other hand, were diagnosed based on the Mahalanobis $\mathrm{D}^{2}$ measure, which should be greater than 0.001 .

Through the exposed model, SEM presents itself as a robust multivariate analysis tool, which has two characteristics that distinguish it from other models: 1) it is a direct approach for estimating multiple and interrelated independence relations, presenting statistical efficiency; and 2) has the ability to present latent constructs, which cannot be measured directly, but through measurable variables or indicators, which are the very questions of the data collection instrument (HAIR et al., 2009).

Thus, the outliers are analyzed and SEM is used to verify the linearity of the data. Initially, the correlations of the variables were analyzed pair by pair using Spearman's correlation matrix, and a significant correlation coefficient at the 5\% level is indicative of the existence of linearity. In addition, the Bartlett test (MINGOTI, 2005) was performed to verify linearity in each construct, since p-values less than 0.05 indicate that there is significant evidence of linearity within the constructs.

The second-order construct "Degree of Maturity of Organizational Processes" (Figure 3) was not formed directly by the items (assertives), but by other latent variables (indicators). Thus, SEM was used with formative constructs. Thus, it was verified whether the weights were significant (greater than zero) and whether the factor loadings were greater than 0.50 (HAIR et al., 2014). Since if there are non-significant weights and low factor loadings, there is no empirical support to keep the indicator in the model. It was also evaluated whether the Variance Inflation Factors were less than 5, thus avoiding multicollinearity problems. In addition, the Bootstrap method was used to calculate the confidence intervals for the weights of the items in the measurement model, which is commonly used to make inferences when the probability distribution of the variable of interest is not known (EFRON; TIBSHIRANI, 1993). In this way, given the original assertions of the instrument adopted, one arrives at those that, in fact, support the indicators in this research and conform the model to assess the 
intended maturity at Cemig. The software used to apply this analysis was the R (version 4.0.2), SEM-PLS library.

\section{RESULTS}

Of the total population of 8,745 employees, it was necessary to reach a minimum sample of five to 10 times the number of items in the survey instrument (SARSTEDT; RINGLE; HAIR, 2011), that is, 240 respondents, considering the 24 assertions pertaining to the constructs. 729 responding individuals were obtained ( $8 \%$ of the population and $203 \%$ above the estimated minimum sample), making up the sample of this research. Data were collected in the period from 14/09/2020 to 17/09/2020.

Regarding the univariate outliers, three values were found outside the range of the scale of their respective variable, that is, observations that were standardized and were outside the range of $|4.00|$. Regarding the multivariate outliers, 13 (1.78\%) observations were identified, since these observations had the significance of the Mahalanobis $\mathrm{D}^{2}$ measure less than 0.001. Despite this, the univariate and multivariate outliers found were not removed from the sample, believing that the observations are valid cases in the population and that, if they were eliminated, they could limit the generality of the multivariate analysis, despite possibly improving its results (HAIR et al., 2009).

Regarding linearity, 276 significant relationships were observed between variables from pair to pair at the $5 \%$ level, which represents $100.00 \%$ of possible correlations by Spearman's correlation matrix. Nevertheless, by the Bartlett test (MINGOTI, 2005) p-values below 0.001 were observed in all constructs. This announces that the variables among themselves and for the constructs (indicators) assume significant linearity.

Regarding the sample, the public has a long period of professional experience, so that $79 \%$ have been working for more than 13 years, and 59\% have been working for more than 21 years (Figure 4). In addition, as shown in Figure 5, respondents have also worked for a long time at the company in question, with $72 \%$ having been working at Cemig for more than 13 years, so that $53 \%$ of the sample has worked for more than 21 years at Cemig. Working time is a relevant factor to verify the level of practical knowledge of those involved in the questions raised in the data collection instrument. 
Figure 4 - Total length of professional experience of survey respondents

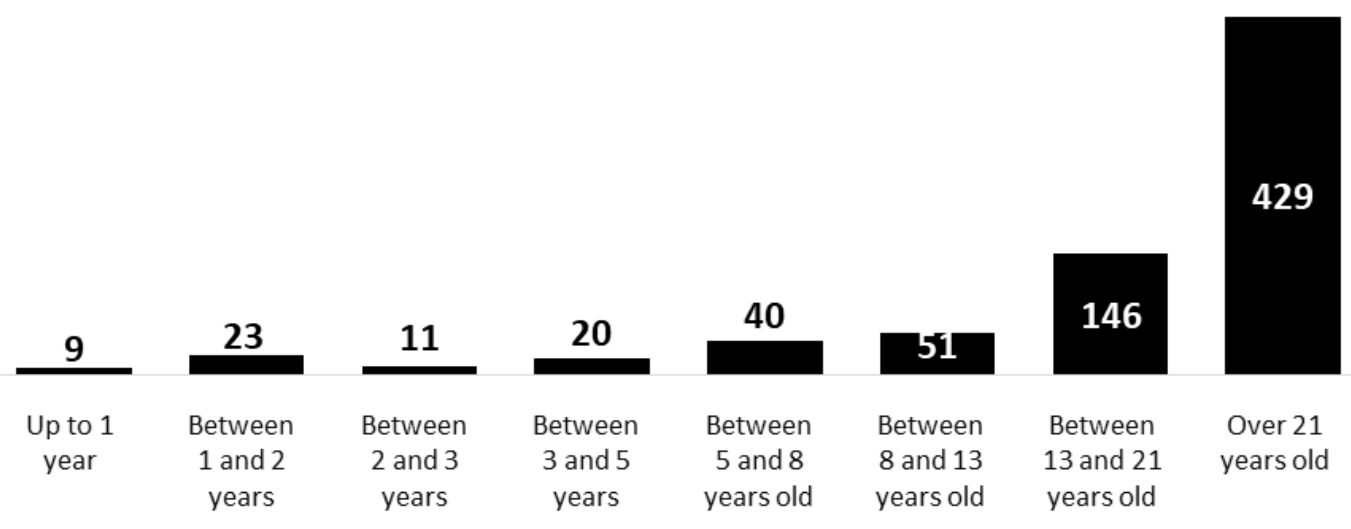

Source: Research data (2021).

Figure 5 - Survey respondents' length of service at Cemig

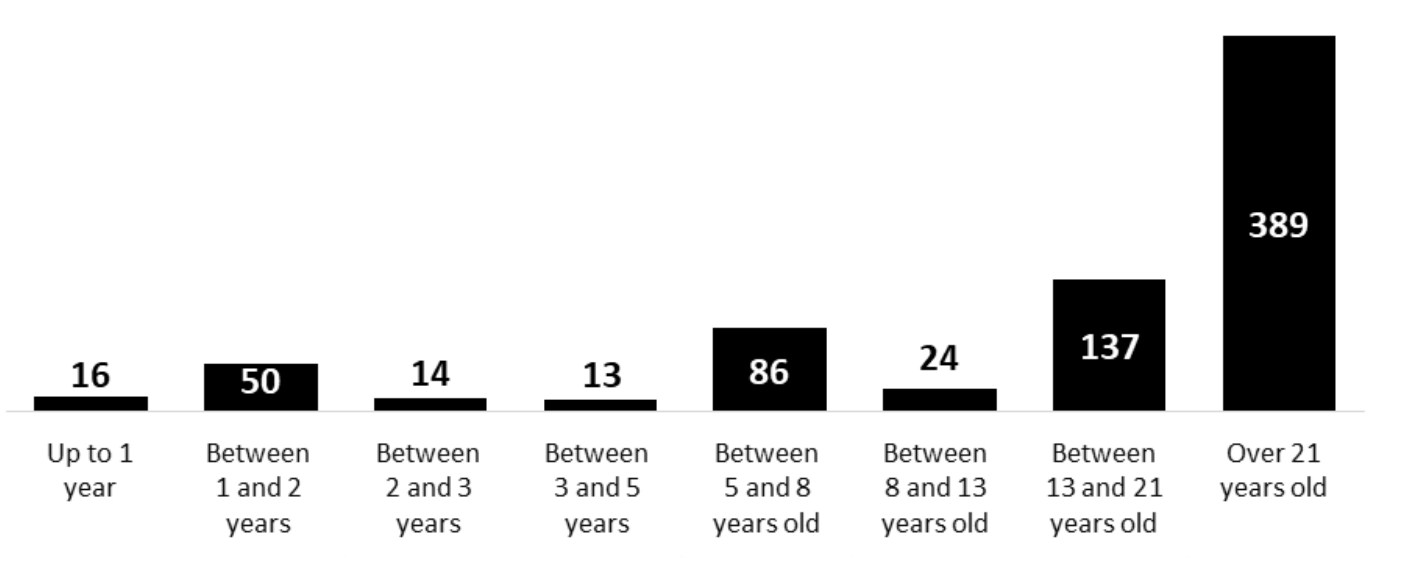

Source: Research data (2021).

The quantitative research consisted of 24 items (assertives) that aim to compose the measurement of each construct to which they are linked. The items were evaluated by the respondents on a scale ranging from 1 "strongly disagree" to 7 "strongly agree". Table 1 shows the mean of the scores obtained by the 729 respondents, as well as their standard deviation and the Bootstrap interval calculated with 95\% confidence. Interval analysis allows the researcher to assess real differences between the scores obtained, verifying the intervals that do not overlap. Furthermore, this interval expresses that if the same survey is carried out, considering the same characteristics of the sample, with $95 \%$ confidence, the mean value will 
be between the value of this interval. Therefore, if the research is applied to similar samples, it is observed that the averages tend to remain close to what was identified.

Table 1 - Results of ratings given by respondents

\begin{tabular}{|c|c|c|c|c|}
\hline Construct & Item Description & Average & S.D. & B. I. $95 \%$ \\
\hline \multirow{8}{*}{ Process design } & Des1 - All processes in our organization are fully documented & 5,10 & 1,51 & [4,99: 5,21] \\
\hline & $\begin{array}{l}\text { Des } 2 \text { - All inputs and outputs of the organization's processes } \\
\text { are clearly defined }\end{array}$ & 4,93 & 1,46 & {$[4,82: 5,03]$} \\
\hline & $\begin{array}{l}\text { Des } 3 \text { - Our organization knows the different needs of our } \\
\text { customers }\end{array}$ & 5,12 & 1,34 & {$[5,01: 5,21]$} \\
\hline & $\begin{array}{l}\text { Des4 - Our organization knows the different needs of our } \\
\text { suppliers }\end{array}$ & 5,04 & 1,29 & {$[4,94: 5,13]$} \\
\hline & $\begin{array}{l}\text { Des5 - Every time a process undergoes changes, its } \\
\text { documentation is immediately updated }\end{array}$ & 4,61 & 1,59 & {$[4,49: 4,74]$} \\
\hline & Des6 - Process design can be adapted based on customer needs & 5,44 & 1,28 & [5,36: 5,54$]$ \\
\hline & $\begin{array}{l}\text { Des } 7 \text { - The process design can be adapted based on the needs } \\
\text { of the suppliers }\end{array}$ & 5,03 & 1,41 & {$[4,93: 5,14]$} \\
\hline & $\begin{array}{l}\text { Des } 8 \text { - The design of organizational processes generates } \\
\text { improvements in the way activities are performed }\end{array}$ & 5,87 & 1,17 & [5,79: 5,95$]$ \\
\hline \multirow{4}{*}{$\begin{array}{l}\text { Executors of the } \\
\text { process }\end{array}$} & $\begin{array}{l}\text { Exe1 - There is full knowledge on the part of all those } \\
\text { responsible for the processes about their performance } \\
\text { indicators }\end{array}$ & 5,14 & 1,39 & [5,04: 5,24$]$ \\
\hline & $\begin{array}{l}\text { Exe } 2 \text { - The organization's employees are duly qualified to } \\
\text { carry out their activities }\end{array}$ & 5,22 & 1,26 & {$[5,13: 5,31]$} \\
\hline & $\begin{array}{l}\text { Exe } 3 \text { - Then performing the tasks, employees faithfully follow } \\
\text { the guidelines contained in the process documentation }\end{array}$ & 5,13 & 1,28 & {$[5,04: 5,22]$} \\
\hline & $\begin{array}{l}\text { Exe } 4 \text { - Process executors have skills that contribute to } \\
\text { improving the execution of activities }\end{array}$ & 5,54 & 1,06 & {$[5,47: 5,62]$} \\
\hline \multirow{3}{*}{ Process owner } & $\begin{array}{l}\text { Prop1 - Employees who take on responsibilities are } \\
\text { distinctively recognized in the organization }\end{array}$ & 4,70 & 1,52 & {$[4,59: 4,80]$} \\
\hline & $\begin{array}{l}\text { Prop2 - Employees who take responsibility for planning } \\
\text { improvements to process designs carry them out in line with } \\
\text { organizational objectives }\end{array}$ & 5,31 & 1,19 & {$[5,22: 5,40]$} \\
\hline & $\begin{array}{l}\text { Prop3 - Employees who take responsibility have authority as a } \\
\text { decision maker }\end{array}$ & 4,97 & 1,37 & {$[4,87: 5,07]$} \\
\hline
\end{tabular}




\begin{tabular}{|c|c|c|c|c|}
\hline & $\begin{array}{l}\text { Prop4 - Process owners assume responsibility for the results } \\
\text { achieved }\end{array}$ & 5,24 & 1,27 & {$[5,15: 5,33]$} \\
\hline \multirow{4}{*}{$\begin{array}{l}\text { Process } \\
\text { infrastructure }\end{array}$} & $\begin{array}{l}\text { Infr } 1 \text { - The organization has adequate information systems that } \\
\text { are aligned with the needs of existing processes }\end{array}$ & 4,92 & 1,44 & {$[4,82: 5,02]$} \\
\hline & $\begin{array}{l}\text { Infr } 2 \text { - Information systems allow interaction between different } \\
\text { organizational areas }\end{array}$ & 4,87 & 1,46 & {$[4,76: 4,97]$} \\
\hline & $\begin{array}{l}\text { Infr3 - The reward system in the organization is aligned with } \\
\text { process performance indicators }\end{array}$ & 4,40 & 1,58 & {$[4,29: 4,52]$} \\
\hline & $\begin{array}{l}\text { Infr } 4 \text { - The information systems have the necessary scope, } \\
\text { contributing to the better performance of activities }\end{array}$ & 4,80 & 1,44 & {$[4,69: 4,90]$} \\
\hline \multirow{4}{*}{$\begin{array}{l}\text { Process } \\
\text { performance } \\
\text { indicators }\end{array}$} & $\begin{array}{l}\text { Idp1 - Process performance indicators are aligned with your } \\
\text { customers' requirements }\end{array}$ & 5,18 & 1,24 & {$[5,08: 5,27]$} \\
\hline & $\begin{array}{l}\text { Idp2 - There is continuous monitoring of the organization's } \\
\text { process indicators }\end{array}$ & 5,62 & 1,24 & {$[5,53: 5,72]$} \\
\hline & $\begin{array}{l}\text { Idp3 - Continuous improvements are initiated regardless of the } \\
\text { performance achieved. }\end{array}$ & 5,05 & 1,36 & {$[4,95: 5,15]$} \\
\hline & $\begin{array}{l}\text { Idp4 - The performance indicators of the organizational } \\
\text { processes used help to identify opportunities for improvement }\end{array}$ & 5,40 & 1,24 & {$[5,30: 5,48]$} \\
\hline
\end{tabular}

Caption: S.D.: Standard deviation; B.I.: Bootstrap Weight Interval with 95\% Confidence.

Source: Research data (2021).

As announced in the methodological procedures, the second-order construct "Degree of Maturity of Organizational Processes" (Figure 3) was not formed directly by the items (assertives), but by other latent variables (indicators). Thus, SEM was used with formative constructs. Table 2 presents the results of the initial formative measurement model, that is, the model proposed and validated by Cardozo (2015), covering all variables and demonstrating the evaluation of the significance and relevance of the first-order formative constructs in this research

Table 2 - Assessment of the significance and relevance of formative constructs - Initial measurement model

\begin{tabular}{cllcccc}
\hline \multirow{2}{*}{ Construct } & \multicolumn{1}{c}{ Item Description } & \multicolumn{4}{c}{ Initial Formative Model } \\
\cline { 3 - 6 } & \multicolumn{1}{c}{$\begin{array}{c}\text { Factor } \\
\text { loading }\end{array}$} & $\begin{array}{c}\text { Commo- } \\
\text { nality }\end{array}$ & $\begin{array}{c}\text { Weight } \\
(\boldsymbol{\beta})\end{array}$ & B.I. 95\% \\
\hline & $\begin{array}{l}\text { Des1 - All processes in our organization are } \\
\text { fully documented }\end{array}$ & $\mathbf{0 , 3 4}$ & 0,11 & $\mathbf{- 0 , 2 0}$ & {$[-0,47 ; 0,05]$} \\
\cline { 2 - 7 } Process design & $\begin{array}{l}\text { Des2 - All inputs and outputs of the } \\
\text { organization's processes are clearly defined }\end{array}$ & $\mathbf{0 , 4 5}$ & 0,20 & 0,13 & {$[-0,13 ; 0,41]$} \\
\cline { 2 - 7 } & $\begin{array}{l}\text { Des3 - Our organization knows the different } \\
\text { needs of our customers }\end{array}$ & 0,68 & 0,47 & 0,47 & {$[0,23 ; 0,70]$} \\
\cline { 2 - 7 } & $\begin{array}{l}\text { Des4 - Our organization knows the different } \\
\text { needs of our suppliers }\end{array}$ & 0,56 & 0,31 & $\mathbf{- 0 , 0 2}$ & {$[-0,26 ; 0,23]$} \\
\hline
\end{tabular}




\begin{tabular}{|c|c|c|c|c|c|}
\hline & $\begin{array}{l}\text { Des5 - Every time a process undergoes changes, } \\
\text { its documentation is immediately updated }\end{array}$ & 0,46 & 0,21 & $-0,04$ & {$[-0,27 ; 0,17]$} \\
\hline & $\begin{array}{l}\text { Des6 - Process design can be adapted based on } \\
\text { customer needs }\end{array}$ & 0,91 & 0,84 & 0,75 & {$[0,54 ; 0,88]$} \\
\hline & $\begin{array}{l}\text { Des } 7 \text { - The process design can be adapted based } \\
\text { on the needs of the suppliers }\end{array}$ & 0,63 & 0,40 & 0,05 & {$[-0,13 ; 0,26]$} \\
\hline \multirow{3}{*}{$\begin{array}{l}\text { Executors of the } \\
\text { process }\end{array}$} & $\begin{array}{l}\text { Exe1 - There is full knowledge on the part of all } \\
\text { those responsible for the processes about their } \\
\text { performance indicators }\end{array}$ & 0,70 & 0,48 & 0,07 & {$[-0,03 ; 0,17]$} \\
\hline & $\begin{array}{l}\text { Exe } 2 \text { - The organization's employees are duly } \\
\text { qualified to carry out their activities }\end{array}$ & 0,94 & 0,89 & 0,63 & {$[0,51 ; 0,75]$} \\
\hline & $\begin{array}{l}\text { Exe3 - When performing the tasks, employees } \\
\text { faithfully follow the guidelines contained in the } \\
\text { process documentation }\end{array}$ & 0,87 & 0,75 & 0,41 & {$[0,26 ; 0,55]$} \\
\hline \multirow{3}{*}{ Process owner } & $\begin{array}{l}\text { Prop1 - Employees who take on responsibilities } \\
\text { are distinctively recognized in the organization }\end{array}$ & 0,80 & 0,64 & 0,26 & {$[0,14 ; 0,39]$} \\
\hline & $\begin{array}{l}\text { Prop2 - Employees who take responsibility for } \\
\text { planning improvements to process designs carry } \\
\text { them out in line with organizational objectives }\end{array}$ & 0,84 & 0,70 & 0,36 & {$[0,22 ; 0,51]$} \\
\hline & $\begin{array}{l}\text { Prop3 - Employees who take responsibility have } \\
\text { authority as a decision makers }\end{array}$ & 0,91 & 0,84 & 0,53 & {$[0,39 ; 0,66]$} \\
\hline \multirow{3}{*}{$\begin{array}{l}\text { Process } \\
\text { infrastructure }\end{array}$} & $\begin{array}{l}\text { Infr1 - The organization has adequate } \\
\text { information systems that are aligned with the } \\
\text { needs of existing processes }\end{array}$ & 0,92 & 0,85 & 0,46 & {$[0,33 ; 0,58]$} \\
\hline & $\begin{array}{l}\text { Infr2 - Information systems allow interaction } \\
\text { between different organizational areas }\end{array}$ & 0,88 & 0,78 & 0,32 & {$[0,20 ; 0,46]$} \\
\hline & $\begin{array}{l}\text { Infr3 - The reward system in the organization is } \\
\text { aligned with process performance indicators }\end{array}$ & 0,82 & 0,67 & 0,35 & {$[0,26 ; 0,44]$} \\
\hline \multirow{3}{*}{$\begin{array}{l}\text { Process } \\
\text { performance } \\
\text { indicators }\end{array}$} & $\begin{array}{l}\text { Idp1 - Process performance indicators are } \\
\text { aligned with your customers' requirements }\end{array}$ & 0,88 & 0,78 & 0,37 & {$[0,24 ; 0,49]$} \\
\hline & $\begin{array}{l}\text { Idp2 - There is continuous monitoring of the } \\
\text { organization's process indicators }\end{array}$ & 0,81 & 0,65 & 0,23 & {$[0,12 ; 0,34]$} \\
\hline & $\begin{array}{l}\text { Idp3 - Continuous improvements are initiated } \\
\text { regardless of the performance achieved }\end{array}$ & 0,92 & 0,85 & 0,54 & {$[0,44 ; 0,64]$} \\
\hline
\end{tabular}

Caption: B.I.: Bootstrap Weight Interval with 95\% Confidence.

Source: Research data (2021).

It is considered that variables with significant weights must have $\beta$ greater than zero and, together, factor loadings with values greater than 0.50 (HAIR et al., 2014) so that there is empirical support to maintain the item in the model. Thus, the items Des1, Des2, Des4 and Des5 were excluded from the model (lines highlighted in Table 2), unlike the model by Cardozo and Rocha (2017), in which the item Infr2 was excluded. In this way, given the original assertions of the instrument adopted, one arrives at those that, in fact, support the indicators in this research and conform the model to assess the intended maturity at Cemig

Next, Table 3 presents the results of the formative measurement model between the five first-order constructs and the second-order global construct. It was evaluated whether the Variance Inflation Factors (VIF) were less than five, thus avoiding multicollinearity problems. The Bootstrap method was used to calculate the confidence intervals for the weights of the items in the measurement model, which is commonly used to make inferences when the probability distribution of the variable of interest is not known (EFRON; TIBSHIRANI, 
1993). All constructs presented high factor loading and VIF less than five, demonstrating the statistical relevance of all first-order constructs, in relation to the second-order construct, called "Degree of Maturity of Organizational Processes".

Table 3 - Modelo de mensuração do construto Grau de Maturidade de Processos Organizacionais

\begin{tabular}{llccccc}
\hline $\begin{array}{c}\text { Second order } \\
\text { construct }\end{array}$ & First order construct & $\begin{array}{c}\text { Factorial } \\
\text { Load }\end{array}$ & Commonality & VIF & $\begin{array}{c}\text { Weight } \\
(\boldsymbol{\beta})\end{array}$ & B.I. 95\% \\
\hline & Process design & 0,78 & 0,60 & 1,82 & 0,22 & {$[0,20 ; 0,22]$} \\
Degree of & Executors of the process & 0,86 & 0,75 & 2,60 & 0,24 & {$[0,23 ; 0,25]$} \\
Maturity of & Process owner & 0,87 & 0,75 & 2,68 & 0,24 & {$[0,23 ; 0,24]$} \\
Organizational & Process infrastructure & 0,87 & 0,76 & 2,51 & 0,27 & {$[0,26 ; 0,27]$} \\
Processes & Process performance & 0,86 & 0,75 & 2,60 & 0,24 & {$[0,22 ; 0,24]$} \\
& indicators & &
\end{tabular}

Caption: VIF: Variance Inflation Factors; $\beta$ : coefficient that quantifies the strength and direction of the relationships between constructs and items; I.C.: Bootstrap weight interval with $95 \%$ confidence. Gof $=61.42 \%$. Source: Research data (2021).

The measurement model graph is shown in Figure 6 and is able to demonstrate the weight of the items in their respective constructs and the second-order constructs in the firstorder constructs, according to the final model obtained by removing the variables Des1, Des2, Des4 and Des5 that had weights $(\beta)$ below zero and factor loadings below 0.50, as described in Table 2.

Figure 6 - Illustration of the Degree of Maturity measurement model in organizational

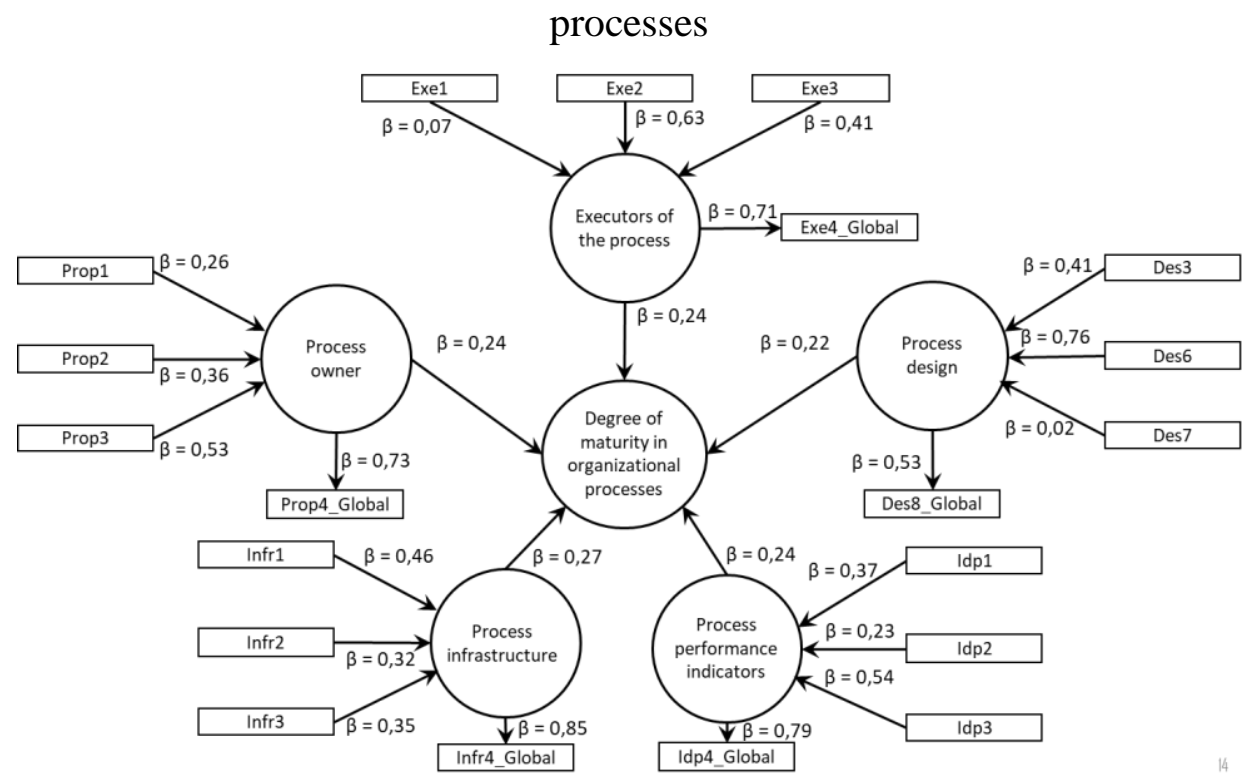

Source: Research data (2021). 
In the SEM developed in the research by Cardozo and Rocha (2017), the item Infr2 was discarded, whereas, in the present study, Des1, Des2, Des4 and Des5 were disregarded, according to the objective criteria for validating items in the SEM. Regarding the SEM constructs, the work of Cardozo (2015) presented the weights in different positions of relevance. The highest weight found by Cardozo (2015) was the construct "Process design" and, in this research, this was the lowest (weight $\beta$ in Table 5). The construct "Process infrastructure", on the other hand, had the greatest weight in this study, and the smallest in Cardozo (2015).

"Infrastructure in the process" considers the Information and Human Resources Systems as the main factor for the management of processes, this being the perspective with the highest weight $(\beta=0.27)$ at Cemig, according to the perspective of the respondents. Therefore, the "Process design", which includes the specification of how the process will be executed, considering purpose, context, documentation, use and updating of the process documentation, as well as segmentation of business processes adhering to customers and the market (CARDOZO, 2015; CARDOZO; ROCHA, 2017) has a lower weight ( $\beta=0.22$ ). This culminates in the understanding that support for processes has greater relevance than their design, and this perspective is different from that found in Cardozo (2015).

Considering that this model aims to verify the influence of first-order constructs on second-order constructs, it is plausible to infer that there is theoretical and empirical coherence in this structure, given that it is substantiated in the literature and statistically validated in organizational soil by this research , in Cardozo (2015) and in Cardozo and Rocha (2017). Thus, first-order constructs positively influence the degree of maturity in process management (second-order construct).

Related to another study on the subject, which used SEM as an analysis methodology, the work of Ongena and Ravesteyn (2019) can be mentioned. The authors highlighted Information Technology as the construct with the greatest weight for organizational performance in BPM, in line with this research, which had infrastructure (basically Information Systems) as the main one. Mamoghli, Cassivi and Trudel (2018) also reinforce Information Technology as one of the most important dimensions of maturity models, referring to the Information Systems that support business processes. The authors also bring the dimension "People" as the second most relevant, which, in this research, is represented by 
the construct "Process executors", which also obtained the second highest weight, according to the SEM.

The study by Cardozo (2015) used, for diagnosis of the Degree of maturity in process management, the traditional CMM model, to measure the degree of maturity in the research process management. For this computation, first, the minimum and maximum marks that could be obtained are found, disregarding the five global indicators, being Exe4_Global, Des8_Global, Idp4_Global, Infr4_Global and Prop4_Global. In the research by Cardozo (2015), it is not clear which were the 18 items considered, so it is assumed that Idp3 was excluded, penultimate item of the construct "Process performance indicators". Thus, considering the amount of 18 items included in the CMM calculation, the minimum score is 1 $\mathrm{x} 18=18$ for all indicators and the maximum score is $7 \times 18=126$, according to the assertions scale, being computed using the sum of the averages of the responses obtained by applying the survey instrument. The CMM has five levels, the difference from 126 to 18 was divided by 5 to compose the intervals of each level $-(126 / 18)=21.6-$, establishing the following range for each stage.

Table 4 - Classification based on the software development process maturity model - CMM

\begin{tabular}{lc}
\hline Level & Punctuation range \\
\hline 1 - Initial & $18-39,6$ \\
2 - Managed & $39,7-61,2$ \\
3 - Defined & $61,3-82,8$ \\
4 - Quantitatively Managed & $82,9-104,4$ \\
5- Optimized & $104,5-126$ \\
\hline
\end{tabular}

Source: Adapted from Cardozo and Rocha (2017, p. 14).

In Cardozo and Rocha (2017), most participating companies (37\%) were allocated to level 3, called "Defined". Considering the calculation presented and disregarding the six items mentioned above, the sum of the averages of the other items shown in Table 1 amounts to 90.73, which is the degree of maturity in Cemig's process management, defined as 4, quantitatively managed. According to company specialists, the ideal score corresponds to the same level. In the diagnosis, according to the BPO model, the level of highest concentration of companies in the study by Cardozo (2015) was 3 - linked, as well as the current level of Cemig. Specialists understand that the ideal for Cemig would be to be at level 4, "Integrated", showing a gap between perspectives. 


\section{CONCLUSION}

This research aimed to assess Cemig's maturity in business process management. For this, it was necessary to identify maturity-oriented data collection instruments and apply them, with a view to verifying whether there is an influence between the factors in the conformation of the intended degree of maturity. Through statistical analysis, it was possible to verify the existence of significant influences and, consequently, to analyze and measure the level of this management within the investigated company.

The main findings are related to opportunities for improvement in the scope of people management and Information Technology. In relation to people management, there are: 1) there is a lack of recognition from those responsible for the processes, who assume additional functions and are responsible for the results achieved in the processes; however, they are not properly recognized by Cemig; 2) the reward system is not properly linked to the results of the process performance indicators, showing a certain misalignment between them. Considering people as the foundation of organizations and people management as an area that targets these individuals, it is essential to consider actions of recognition and reward for the maintenance of these individuals and improvement of the processes assigned to them.

With regard to Information Technology, we emphasize: 1) Information Systems could be more aligned with the needs of customers and allow greater interaction between different organizational areas. Technology presents itself as a means for a certain organizational purpose and, therefore, must be oriented to the customers' needs, given that this justifies the existence of the business. In this sense, the business process is a set of activities oriented to represent value to the customer and BPM promulgates a firm direction to that. In this way, it becomes plausible to align the Information Systems with the needs of customers so that these reflect business results, considering these connections as feedback. The aforementioned aspects are points of improvement, given that they are linked to the construct "Process infrastructure", with greater weight from the perspective of the respondents in this research.

It is believed that this research contributes by establishing the continuity of investigations related to process management, from the perspective of maturity represented by the point of view of professionals who work in the daily business. Nevertheless, science advances through further research and, therefore, it is believed that this investigation contributes by being grounded in past studies, reaffirming the need to continue research based on previous achievements and, therefore, promoting cumulative science. 
It should be noted that Cemig's degree of maturity in business process management is 4 - quantitatively managed - according to the CMM, and 3 - linked - according to the BPO model. This announces that there is a divergence between the models, as well as the perception of the company's professionals in relation to this second stage, culminating in the possibility of future studies to investigate: 1) the distinctions between the models to provide different levels of maturity; and 2) the gap between the experts' perception regarding the result computed by the BPO model. Nevertheless, it is considered to expand this research to organizations from other segments, aiming to compare the results of the SEM measurement model between different economic sectors.

\section{References}

CARDOZO, E. A. A. A maturidade da estrutura organizacional e dos processos como direcionadores do desempenho, 2015. Dissertação (Mestrado em Administração) - Centro de Ciências Jurídicas e Econômicas. Universidade Federal do Espírito Santo. Vitória - ES, 2015.

CARDOZO, E. A. A.; ROCHA, K. M. Avaliação do grau de maturidade dos processos organizacionais com enfoque nos habilitadores. In: ENCONTRO NACIONAL DE ENGENHARIA DE PRODUÇÃO. Anais... XXXVII ENEGEP, Joinville - SC, 2017.

CBOK. Guia para o Gerenciamento de Processos de Negócio: Corpo Comum de Conhecimento (3.0). Brasil: ABPMP, 2013.

COBB, C. G. From Quality to Business Excellence: A Systems Approach to Management. Milwaukee, Wis: Asq Pr. 2003.

CROSBY, P. Quality is free: The art of making quality certain. New York: Penguin Books Ltd., 1980.

EFRON, B.; TIBSHIRANI, R. J. Introduction to the Bootstrap. Chapman \& Hall: New York, 1993.

ESCRIVÃO, G.; SILVA, S. L. Maturidade da gestão do conhecimento: a importância da infraestrutura organizacional para o desenvolvimento dos estágios. Perspectivas em Ciência da Informação, v. 25, p. 218-241, 2021.

FISHER, D. M. The business process maturity model: a practical approach for identifying opportunities for optimization. Business Process Trends, v. 9, n. 4, p. 11-15, 2004.

FROGER, Manon et al. A non-linear business process management maturity framework to apprehend future challenges. International Journal of Information Management, v. 49, p. 290-300, 2019. DOI: https://doi.org/10.1016/j.ijinfomgt.2019.05.013 
HAIR, J. F. et al. Análise Multivariada de Dados. Porto Alegre: Bookman, 2009.

HAIR, J. F. et al. A Primer on Partial Least Squares Structural Equation Modeling (PLS-SEM). Los Angeles: SAGE Publications, Incorporated, 2014.

HAMMER, M. The Process Audit. Harvard Business Review, 2007.

HAMMER, M.; HERSHMAN, L. W. Mais rápido, barato e melhor. 1a. Alta Books, 2017.

HARMON, P. The State of Business Process Management 2018. $<$ https://www.bptrends.com/2018-state-of-business-process-management-lp/>. 2018. Acesso em: 31 ago. 2019.

HARRINGTON, H. J. Process Management Excellence: The Art of Excelling in Process Management. Chico, Calif: Paton Press, 2006.

HELGESSON, Y. Y. L.; HÖST, M.; WEYNS, K. A review of methods for evaluation of maturity models for process improvement: a review of methods for evaluation of maturity models. Journal of Software: Evolution and Process, v. 24, n. 4, p. 436-454, 2012. DOI: https://doi.org/10.1002/smr.560

HUMPHREY, W. S. Characterizing the software process: A maturity framework. IEEE Software, v. 5, n. 2, p. 73-79, 1988. DOI: https://doi.org/10.1109/52.2014

IVERSEN, J.; NIELSEN, P. A.; NORBJERG, J. Situated Assessment of Problems in Software Development. SIGMIS Database, v. 30, n. 2, p. 66-81, 1999. DOI: https://doi.org/10.1145/383371.383376

KALINOWSKI, T. B. Analysis of business process maturity and organisational performance relations. Management, v. 20, n. 2, p. 87-101, 2016. DOI: https://doi.org/10.1515/manment2015-0052

LIZANO-MORA, H.; PALOS-SÁNCHEZ, P. R.; AGUAYO-CAMACHO, M. The Evolution of Business Process Management: A Bibliometric Analysis. IEEE Access, v. 9, p. 5108851105, 2021. DOI: https://doi.org/10.1109/ACCESS.2021.3066340

MALHOTRA, N. Pesquisa De Marketing Uma Orientação 4Ed. * (Edição: 4a). Porto Alegre: Bookman, 2006.

MAMOGHLI, S.; CASSIVI, L.; TRUDEL, S. Supporting business processes through human and IT factors: a maturity model, Business Process Management Journal, v. 24, n. 4, p. 985-1006, 2018. DOI: https://doi.org/10.1108/BPMJ-11-2016-0232

MARQUES, J. M. R. et al. A Maturidade da Gestão do Conhecimento: uma comparação entre a percepção de docentes e técnicos administrativos de uma Instituição Pública de Ensino Superior. Revista Conhecimento Online, v. 12, n. 1, p. 27-48, 2020.

MCCORMACK, K. P.; JOHNSON, W. C. Business process orientation: Gaining the ebusiness competitive advantage. Crc Press, 2001. 
MEIDAN, A. et al. A survey on business processes management suites. Computer $\begin{array}{llllllll}\text { Standards } \quad \boldsymbol{\&} \text { Interfaces, } & \text { v. } 51, \quad \text { p. } 71-86, & \text { DOI: }\end{array}$ https://doi.org/10.1016/j.csi.2016.06.003

MINGOTI, S. A. Análise de dados através de métodos de estatística multivariada: uma abordagem aplicada. Belo Horizonte: Editora UFMG, 2005.

NEVES, M. E.; FERREIRA, E. P.; PARREIRAS, F. S. Modelos de maturidade em gestão por processos de negócios (BPM): um estudo terciário. Pesquisa Brasileira em Ciência da Informação e Biblioteconomia, v. 15, p. 1-14, 2020.

NOLAN, R. L. Managing the computer resource: A stage hypothesis. Communications of the ACM, v. 16, n. 7, p. 399-405, 1973. DOI: https://doi.org/10.1145/362280.362284

OMG. Business Process Maturity Model (BPMM) (1.0), 2008. Disponível em: <http://www.omg.org/spec/BPMM/1.0/PDF>. Acesso em 18 ago 2020.

ONGENA, G.; RAVESTEYN, P. Business process management maturity and performance: A multi group analysis of sectors and organization sizes. Business Process Management Journal, v. 26, n. 1, p. 132-149, 2019. DOI: https://doi.org/10.1108/BPMJ-08-2018-0224

ROSEMANN, M. Proposals for Future BPM Research Directions. Asia Pacific Business Process Management, v. 181, p. 1-15, 2014. DOI: https://doi.org/10.1007/978-3-319$\underline{08222-6 \_1}$

ROSEMANN, M.; BRUIN, T. Towards a business process management maturity model. In: PROCEEDINGS OF THE THIRTEENTH EUROPEAN CONFERENCE ON INFORMATION SYSTEMS. Anais... ECIS 2005., 13, 2005, p. 26-28.

SARSTEDT, M.; RINGLE, C. M.; HAIR, J. F. PLS-SEM: Indeed a Silver Bullet. Journal of Marketing Theory and Practice, v. 19, n. 2, p. 139-152, 2011.

SZELAGOWSKI, M.; BERNIAK-WOŹNY, J. The adaptation of business process management maturity models to the context of the knowledge economy. Business Process Management Journal, v. 26, n. 1, p. 212-238, 2020. https://doi.org/10.1108/BPMJ-11-2018$\underline{0328}$

VAN LOOY, A. Business Process Maturity, 2014. Disponível em: <http://link.springer.com/10.1007/978-3-319-04202-2>. Acesso em: 20 jul. 2021.

VAN LOOY, A.; DE BACKER, M.; POELS, G. Defining business process maturity. A journey towards excellence. Total Quality Management \& Business Excellence, v. 22, n. 11, p. 1119-1137, 2011. DOI: https://doi.org/10.1080/14783363.2011.624779 